\title{
РЕАКЦІЯ РЕДОКС-СИСТЕМИ НА ДІЮ ОКРЕМИХ ЗАСОБІВ ДЛЯ НАРКОЗУ ЗА УМОВ ЕКСПЕРИМЕНТАЛЬНОГО ГІПЕРТИРЕОЗУ
}

\section{Реакція редокс-системи на дію окремих засобів для наркозу за умов експериментального гіпертиреозу}

\section{О. М. Якимчук, І. М. Кліщ}

Тернопільський національний медичний університет імені І. Я. Горбачевського МОЗ України

Резюме. Досліджено особливості функціонування редокс-системи у відповідь на дію різних медикаментів для наркозу за умов гіпертиреозу в експерименті. Встановлено, що при експериментальному гіпертиреозі інтенсивність вільнорадикального окиснення за дії різних засобів для наркозу проявляється активніше, ніж за умови евтиреозу та супроводжується виснаженням активності фрерментів антиоксидантної системи (каталази, відновленого глютатіону, глутатіон-пероксидази, супероксиддисмутази та церулоплазміну).

Мета дослідження - 3'ясувати особливості реакції редокс-системи дослідних тварин на дію різних засобів для наркозу за умов попередньо змодельованого гіпертиреозу.

Матеріали і методи. Для моделювання стану гіпертиреозу щурам вводили L-тироксин протягом 21-ї доби. Порівнювали особливості реагування редокс-системи на введення тіопенталу натрію та дексмедитомедину за умов евтиреозу та гіпертиреозу.

Результати. У плазмі крові тварин з експериментальним гіпертиреозом спостерігали підвищення рівня ТБК-активних продуктів та достовірну відмінність при застосуванні тіопенталу натрію та дексмедитомедину гідрохлориду на активність фрерментів антиоксидантного захисту за умов гіпер- та евтиреозу.

Висновки. Активація обмінних процесів на тлі підвищеної функції щитоподібної залози впливає на універсальні захисні системи захисту організму, що проявляються особливо яскраво в умовах операційного та періопераційного стресу активацією редокс-системи й виснаженням фрерментів антиоксидантного захисту, що зумовлює пошук засобів медикаментозної корекції порушеного гомеостазу.

Ключові слова: вільнорадикальне окиснення; ферменти антиокисантного захисту; гіпертиреоз; тіопентал натрію; дексмедитомедин.
Response of the redox system to the effect of various drugs for anesthesia under experimental hyperthyroidism

O. M. Yakimchuk, I. M. Klishch

I. Horbachevsky Ternopil National Medical University e-mail: sasha_yakymchuk@ukr.net

Summary. The peculiarities of the processes of the redox system on the action of various drugs for anesthesia under conditions of hyperthyroidism in the experiment were studied. It was found that in experimental hyperthyroidism the intensity of free radical oxidation on the background of various drugs for anesthesia is more active than in euthyroidism and is accompanied by depletion of enzymes of the antioxidant system (catalase, reduced glutathione, glutathione peroxidase, superoxiddysmutase).

The aim of the study - to find out the peculiarities of the reaction of the redox system of experimental animals under the conditions of simulated hyperthyroidism to the action of various drugs for anesthesia.

Materials and Methods. Rats were injected with L-thyroxine for 21 days to simulate the state of hyperthyroidism. We compared the effect of euthyroidism and hyperthyroidism on the state of the redox system on the introduction of sodium thiopental and dexmedetomedine in the experiment.

Results. In the plasma of animals with experimental hyperthyroidism, an increase in the level of TBA-active products (initial and final products of free radical oxidation of lipids) and a significant difference in the effect of sodium thiopental and dexmedetomedine hydrochloride on the activity of antioxidant enzymes under hyper- and hyporthyroidism.

Conclusions. Activation of metabolic processes of the thyroid gland affects the universal protective systems of the body, which are especially pronounced under operational and perioperative stress by activating the redox system and depletion of antioxidant enzymes, which leads to the search for drugs to correct homeostasis.

Key words: free radical oxidation; antioxidant enzymes; hyperthyroidism; sodium thiopental; dexmedetomedine. 


\section{ВСТУП}

Збільшення частоти поширення гіпертиреозу зумовлює доцільність проведення експериментальних досліджень для подальшого вивчення механізмів впливу тиреоїдних гормонів на особливості метаболічних процесів за умов застосування медикаментозних засобів у цих пацієнтів [1, 2]. Високі ризики інтра- і післяопераційних ускладнень пов'язані з безпосереднім токсичним впливом надлишку гормонів щитоподібної залози (ЩЗ) на серцево-судинну, нервову та інші системи організму [1-3], а також особливостями, зумовленими дією лікарських засобів на тлі гіпертиреозу. Високий ступінь варіабельності цих впливів на організм обґрунтовує актуальність проблеми оптимізації анестезіологічної допомоги при ургентних операціях з приводу різних нозологій на тлі патології щ3, що посилюється при періопераційному стресі [4].

Більшість патологічних процесів в організмі $\epsilon$ універсальними. Одним із таких механізмів - прота антиоксидантна системи захисту [5-7]. Особливість впливу гіперфункції щитоподібної залози на процеси вільнорадикального окиснення, утворення активних форм кисню на процеси, які виконують численні регуляторні фрункції, $є$ не до кінця зрозумілими.

Метою дослідження було з'ясувати особливості реакції редокс-системи дослідних тварин на дію різних засобів для наркозу за умов змодельованого гіпертиреозу.

\section{МАТЕРІАЛИ I МЕТОДИ}

Дослідження виконано на 60 статевозрілих безпородних білих щурах-самцях масою тіла

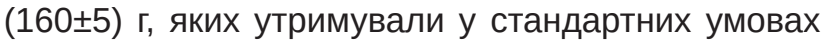
віварію. Усі маніпуляції з експериментальними тваринами проводили із дотриманням правил Європейської конвенції про захист хребетних тварин, що використовуються для дослідних та інших наукових цілей, а також згідно з Науково-практичними рекомендаціями з утримання лабораторних тварин та роботи з ними [8].

Дослідних тварин поділили на такі групи: перша - інтактна (10 щурів); друга - тваринам було змодельовано експериментальний гіпертиреоз (10 щурів); третя - тваринам вводили тіопентал натрію на тлі еутирозу (10 щурів); четверта група отримувала тіопентал натрію на тлі експериментального гіпертиреозу (10 щурів); п'ята - тваринам вводили дексмедитомедин на тлі евтиреозу (10 щурів), шоста група - вводили дексмедитомедин на тлі експериментального гіпертиреозу (10 щурів) (табл. 1).

Гіпертиреоз моделювали шляхом інтрагастрального введення L-тироксину на $1 \%$ розчині крохмалю по 200 мкг/добу на 1 кг маси тіла щоденно протягом 21-ї доби $[2,13]$. Тіопентал натрію вводили внутрішньочеревно 3 розрахунку 20 мг/кг маси тіла щура $[9,10]$. Дексмедитомедину гідрохлорид вводили внутрішньочеревно з розрахунку 1 мкг/кг маси тіла тварини [11].

Рівень оксидативного стресу в щурів вивчали за вмістом у плазмі крові дієнових конюгат (ДК) за методом, описаним В. Б. Гавриловим [12] і ТБК-активних продуктів, як описано у роботі І. Д. Стальної [14]. Ефективність системи антиоксидантного захисту оцінювали за активністю супероксиддисмутази, каталази, церулоплазміну. Визначали також стан глутатіонової системи. Активність супероксиддисмутази визначали за методикою С. Чевари, І. Чаба, Й. Секей (1985) у модифрікації Е. Е. Дубиніної (1988) [15]. Каталазну активність визначали за методом М. А. Королюка та співавт. [16].

Цисровий матеріал, отриманий в результаті експерименту, систематизували та обробили за допомогою методів варіаційної статистики 3 використанням програми «Microsoft Exel».

\section{РЕЗУЛЬТАТИ Й ОБГОВОРЕННЯ}

Результати дослідження мембранотоксичної дії різних засобів для наркозу при експериментальному гіпертиреозі оцінювали за активністю ферментної антиоксидантної системи захисту та показників ліпопероксидації.

Аналізотриманихрезультатівпоказав, щоекспериментальний гіпертиреоз значно активує процеси редокс-системи. Порівняно 3 евтиреозом, гіпертиреоз спричиняв зростання початкових продуктів пероксидного окиснення ліпідів. Концентрація ДК у сироватці крові дослідних тварин зростала і становила відповідно у першій групі тварин $(1,18 \pm 0,07)$ ум. од. та $(2,21 \pm 0,05)$ ум. од. - в другій $(p<0,05)$. Застосування тіопенталу за умови евтиреозу

Таблиця 1. Поділ тварин на групи

\begin{tabular}{l|c|l}
\hline \multicolumn{1}{|c|}{ Група тварин } & Кількість тварин & \multicolumn{1}{c}{ Вид знеболювання } \\
\hline Перша & 10 & Евтиреоз \\
\hline Друга & 10 & Гіпертиреоз \\
\hline Третя & 10 & Тіопентал натрію + еутироз \\
\hline Четверта & 10 & Тіопентал натрію + гіпертиреоз \\
\hline П'ята & 10 & Дексмедитомедин + евтиреоз \\
\hline Шоста & 10 & Дексмедитомедин + гіпертиреоз \\
\hline
\end{tabular}


(третя група) призводить до зростання ДК в 1,1 раза, відповідно $(1,34 \pm 0,08)$ ум. од. $(p<0,05))$. В четвертій групі тварин при експериментальному гіпертиреозі та застосуванні тіопенталу натрію ці показники досягають значення $(2,56 \pm 0,13)$ ум. од., що відповідно в 1,6 раза перевищує показники інтактних тварин $(p<0,05)$. За умови застосування дексмедитомедину при евтиреозі (п'ята група) рівень ДК становив $(1,29 \pm 0,09)$ ум. од. та $(2,32 \pm 0,09)$ ум. од. $(p<0,05)$ відповідно при гіпертиреозі (шоста група) (табл. 2).

Показники ТБК-активних продуктів зростали в 1,8-1,9 раза порівняно 3 групою інтактних тварин. Так, початкові продукти пероксидного окиснення ліпідів (дієнові кон'югати) досягали рівня $(1,18 \pm 0,07)$ ум. од. при еутирозі та $(2,21 \pm 0,05)$ ум. од. - при гіпертиреозі в експериментальних тварин $(p<0,05)$ порівняно з групою інтактних тварин. Концентрація проміжного показника пероксидного окиснення ліпідів - малонового діальдегіду (МДА) при евтиреозі склала $(3,67 \pm 0,6)$ мкмоль/л, а при експериментальному гіпертиреозі зростала до $(7,05 \pm 0,14)$ мкмоль/л $(p<0,05)$.

При уведенні тіопенталу натрію (третя група) та дексмедитомедину (п'ята група) в евтиреоїдних тварин концентрація ТБК-активних продуктів у сироватці крові тварин зростала. Зокрема, концентрація МДА у тварин третьої групи склала $((4,83 \pm 0,13)$ мкмоль/л), що у 1,3 раза $(p<0,05)$ вище від норми, а у п'ятій групі тварин, яким використо-

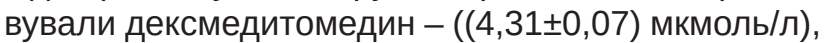
що у 1,2 раза вище порівняно з показниками у групі інтактних тварин $(p<0,05)$.

Гіпертиреоз супроводжується посиленням процесів вільнорадикального окиснення. Зафріксовано суттєве зростання активності МДА в групах із змодельованим гіпертиреозом при введенні тіопенталу натрію (четверта група) у 2,1 раза $((7,84 \pm 0,10)$ мкмоль/л $(p<0,05))$ та 1,8 раза
$((6,79 \pm 0,16)$ мкмоль/л $(p<0,05))$ у групі з дексмедитомедином (шоста група) (табл. 2).

Дисбаланс у системі антиоксидантного захисту виникає за рахунок різкого виснаження їі фрерментної ланки для знешкодження пулу вільних радикалів, ініційованих експериментальним гіпертиреозом.

На першій лінії захисту від негативного впливу активних форм оксигену основну роль відіграє супероксиддисмутаза. Відзначалося достовірне зниження активності СОД у 1,4 раза в другій групі тварин із змодельованим гіпертиреозом порівняно 3 показниками інтактних тварин $(p<0,05)$. При застосуванні тіопенталу натрію на тлі евтиреозу (третя група) та дексмедитомедину (п'ята група) відмічається зниження супероксиддисмутазної активності на 14 та 13 \% порівняно з інтактними тваринами ( $>>0,05)$. Більш вираженим (у 1,7 раза) було зниження ензимної активності на тлі гіпертиреозу в четвертій групі, де використовувався тіопентал натрію, та у 1,3 раза в шостій групі тварин, яким вводили дексмедитомедин ( $>0,05)$.

Як відомо, каталаза нейтралізує токсичний пероксид водню, який утворюється під дією СОД. Отримані результати експерименту показали, що в групі тварин із змодельованим гіпертиреозом (друга група), активність каталази достовірно знижувалась

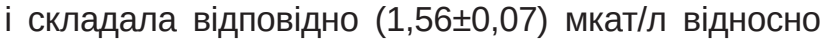
інтактних тварин (перша група) $(2,89 \pm 0,11)$ мкат/л $(p<0,05)$. У третій групі тварин на тлі евтиреозу та уведення тіопенталу натрію та п'ятій групі (на тлі дексмедитомедину) відмічалося незначне зниження рівня каталази - в 1,4 раза $(2,02 \pm 0,17)$ мкат/л та 1,1 раза $(2,62 \pm 0,05)$ мкат/л відповідно $(p<0,05)$.

При застосуванні засобів для наркозу в групах тварин із гіпертиреозом відбулося суттєве зниження активності каталази у плазмі щурів $(p<0,05)$ : в 4,1 раза у четвертій групі при введені тіопенталу натрію та в 2,3 раза у шостій за умови введення дексмедитомедину.

Таблиця 2. Активність редокс-системи у тварин з експериментальним гіпертиреозом за умови застосування різних

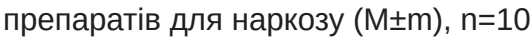

\begin{tabular}{|c|c|c|c|c|c|c|}
\hline Показник & Перша група & Друга група & $\begin{array}{l}\text { Третя } \\
\text { група }\end{array}$ & $\begin{array}{l}\text { Четверта } \\
\text { група }\end{array}$ & П'ята група & $\begin{array}{l}\text { Шоста } \\
\text { група }\end{array}$ \\
\hline МДА, мкмоль/л & $3,67 \pm 0,6$ & $7,05 \pm 0,14^{*}$ & $4,83 \pm 0,13^{*}$ & $7,84 \pm 0,1^{*}$ & $4,31 \pm 0,07^{*}$ & $6,79 \pm 0,16^{\star}$ \\
\hline ДК, ум. од./мл & $1,18 \pm 0,07$ & $2,21 \pm 0,05^{\star}$ & $1,34 \pm 0,08^{*}$ & $2,56 \pm 0,13^{*}$ & $1,29 \pm 0,09^{*}$ & $2,32 \pm 0,09$ \\
\hline Каталаза, мкат/л & $2,89 \pm 0,11$ & $1,56 \pm 0,07^{*}$ & $2,02 \pm 0,17^{*}$ & $0,69 \pm 0,16^{*}$ & $2,62 \pm 0,05^{*}$ & $1,21 \pm 0,09 *$ \\
\hline СОД, ум. од. & $2,97 \pm 0,19$ & $2,05 \pm 0,006^{*}$ & $2,54 \pm 0,1^{*}$ & $1,78 \pm 0,09 *$ & $2,59 \pm 0,08$ * & $2,14 \pm 0,08^{\star}$ \\
\hline $\begin{array}{l}\text { Глутатіон-пероксидаза, } \\
\text { ммоль/л }\end{array}$ & $0,147 \pm 0,008$ & $0,087 \pm 0,015^{\star}$ & $0,131 \pm 0,014^{*}$ & $0,072 \pm 0,012^{*}$ & $0,137 \pm 0,005^{*}$ & $0,125 \pm 0,006$ \\
\hline $\begin{array}{l}\text { Глутатіон-редуктаза, } \\
\text { ммоль/л }\end{array}$ & $0,091 \pm 0,006$ & $0,064 \pm 0,007 *$ & $0,087 \pm 0,006$ & $0,062 \pm 0,008^{*}$ & $0,088 \pm 0,004^{*}$ & $0,073 \pm 0,007$ \\
\hline $\begin{array}{l}\text { Відновний глутатіон, } \\
\text { ммоль/л }\end{array}$ & $2,95 \pm 0,15$ & $1,87 \pm 0,01^{*}$ & $2,46 \pm 0,13^{*}$ & $1,73 \pm 0,18^{\star}$ & $2,61 \pm 0,23^{*}$ & $1,85 \pm 0,11$ \\
\hline Церулоплазмін, мг/л & $20,97 \pm 0,51$ & $13,58 \pm 0,58^{*}$ & $17,10 \pm 0,45^{*}$ & $11,14 \pm 0,82^{*}$ & $18,93 \pm 0,75^{\star}$ & $13,45 \pm 0,96 *$ \\
\hline
\end{tabular}

Примітка. * - величини, які статистично достовірні щодо аналогічних показників у групі інтактних тварин (р<0,05).

ISSN 2706-6282(print)

ISSN 2706-6290(online)
Вісник медичних і біологічних досліджень Bulletin of Medical and Biological Research 
Важливе значення у процесі захисту клітин від вільних радикалів відіграє глутатіонова система, яка складається 3 ферментів глутатіон-пероксидази та глутатіон-редуктази, а також відновленого глутатіону. При експериментальному гіпертиреозі (друга група) виникає виснаження системи антиоксидантного захисту. Так, концентрація відновленого глутатіону знизилася в 1,5 раза $(1,87 \pm 0,01)$ ммоль/л $(p<0,05)$, глутатіонпероксидази - у 1,7 раза $(0,087 \pm 0,015)$ ммоль/л, глутатіон-редуктази - в 1,4 раза $(0,064 \pm 0,007)$ ммоль/л відносно групи здорових тварин.

На тлі евтиреозу в умовах проведення наркозу тіопенталом натрію (третя група) відбувається незначне зниження активності глутатіон-редуктази відповідно в 1,1 раза ( $>>0,05)$. Рівень відновленого глутатіону в третій групі знижувався в 1,2 раза. При порівнянні активності глутатіон-пероксидази та глутатіон-редуктази в п'ятій групі на тлі евтиреозу та застосовуванні дексмедитомедину відзначається незначне зниження активності (на 4 та $7 \%$ ) (p>0,05). Рівень відновного глутатіону становив $(2,61 \pm 0,23)$ ммоль/л, що було нижче показників групи інтактних тварин на $12 \%(p<0,05)$.

Гіпертиреоз спричиняє достовірне зниження вмісту глутатіон-пероксидази в четвертій та шостій групах в 2,4 та 1,2 раза ( $<<0,05)$ та зменшення рівня глутатіон-редуктази - в 1,4 та 1,2 раза в четвертій та шостій групах відповідно $(p<0,05)$. Рівень відновного глутатіону в четвертій та шостій групах знижував-

\section{СПИСОК ЛІТЕРАТУРИ}

1. American Thyroid Association Management Guidelines for Adult Patients with Thyroid Nodules and Differentiated Thyroid Cancer: The American Thyroid Association Guidelines Task Force on Thyroid Nodules and Differentiated Thyroid Cancer / B. R. Haugen, E. K. Alexander, K. C. Bible [et al.] // Thyroid. - 2016. Vol. 26, No. 1. - P. 1-133

2. Нечипорук В. М. Вплив тиреоїдних гормонів на процеси реметилування та транссульфування сірковмісних амінокислот в органах щурів / В. М. Нечипорук, Н. В. Заічко, М. М. Корда // Медична та клінічна хімія. 2017. - T. 19, № 1. - С. 12-16.

3. Homocysteine, folate, and cobalamin levels in hyperthyroid women before and after treatment / A. Orzechowska-Pawilojc, M. Siekierska-Hellmann, A. Syrenicz [et al.] // Endokrynol. Pol. - 2009. - Vol. 60, No. 6. - P. 443-448.

4. Сомова О. В. Взаємозв'язок тиреоїдного стану організму та процесів перекисного окислення ліпідів : авторефр. дис. на здобуття наук. ступеня канд. біол. наук / О. В. Сомова. - Харків, 1999. - 11 с.

5. Клинический протокол послеоперационного ведения больных диффреренцированным раком щитовидной железы / В. А. Олейник, В. В. Марков, С. В. Гулеватый [и др.] // Ліки України. - 2010. - Т. 146, № 10. - С. 73-75. ся відповідно в 1,5 раза $(1,73 \pm 0,18)$ ммоль/л та в 1,6 раза і становив $(1,85 \pm 0,11)$ ммоль/л, що достовірно відрізнялось від групи інтактних тварин $(p<0,05)$.

При гіпертиреозі (друга група) активність церулоплазміну $(13,58 \pm 0,18)$ мг/л зменшується в 1,5 раза порівняно 3 показниками інтактних тварин $(20,97 \pm 0,26)$ мг/л, $(p<0,05)$. На тлі евтиреозу та застосуванні тіопенталу натрію (третя група) та дексмедитомедину (п'ята) відмічається зниження церулоплазміну в 1,2 та 1,1 раза порівняно 3 показниками інтактних тварин ( $>0,05)$. У групах із змодельованим гіпертиреозом та застосуванням тіопенталу натрію (четверта) та дексмедитомедину (шоста) відмічається зниження церулоплазміну в 1,9 та 1,7 раза порівняно з показниками інтактних тварин $(p<0,05)$.

Ці показники свідчать, що в умовах експериментального гіпертиреозу токсична дія засобів для наркозу проявляється більш виражено порівняно 3 евтиреоїдними тваринами.

\section{ВИСНОВкИ}

Активація вільнорадикальних процесів призвордить до зростання рівня початкових та кінцевих продуктів ПОЛ, зриву фрізіологічних компенсаторних процесів та значного виснаження активності фрерментів антиоксидантної системи, що $є$ основою для рекомендацій застосувати додаткову терапію у комплексній періопераційній підготовці на тлі гіпертиреозу.

6. Марущак М. І. Роль активних фрорм кисню у розвитку і прогресуванні гострого ураження легень в експерименті / М. І. Марущак // Медична хімія. - 2012. - Т. 14, № 1. - С. 104-108.

7. Антонишин І. В. Стан пероксидного окиснення ліпідів при експериментальному дієтіндукованому аліментарному ожирінні / І. В. Антонишин, М. І. Марущак, О. В. Денефіль // Медична хімія. - 2014. - Т. 16, № 3. C. 61-65.

8. Науково-практичні рекомендації з утримання лабораторних тварин та роботи з ними / Ю. М. Кожем'якін, О. С. Хромов, М. А. Філоненко, Г. А. Сайфетдінова. - К. : Авіцена, 2002. - 156 с.

9. Пат. України на корисну модель № (19)UA (11)3386 (13)U 7 A61B17/00,A61K31/00 (54) Спосіб знеболювання у щурів при оперативних втручаннях на шлунку / Степанюк Г. І., Шевчук О. К. - Вінницький національний медичний університет ім. М. І. Пирогова. - Бюл. № 11, 2004 р. - 15.11.2004.

10. Харкевич Д. А. Фармакология : учебник для студ. мед. вузов / Д. А. Харкевич. - Москва : Медицина, 1981. - С. 133.

11. Павлов О. О. Місце $\alpha_{2}$-агоністів у комплексі схеми знеболювання / О. О. Павлов, Е.В.Подрез // Медицина неотложних состояний. - 2014. - № 8 (63). - С. 9-12. 
12. Гаврилов В. Б. Спектрофротометрическое определение содержания гидроперекисей липидов в плазме крови / В. Б. Гаврилов, М. И. Мишкорудная // Лаб. дело. - 1983. - № 3. - С. 33-36.

13. Перекисное окисление липидов у больных дифрфузным токсическим зобом и гипотиреозом / Е. С. Ром-Бугуславская, Е. В. Сомова, Т. С. Гринченко [и др.] // Врач. дело. -1998. - № 1. - С. 88-91.

14. Стальная И. Д. Метод определения малонового диальдегида с помощью тиобарбитуровой кислоты /

\section{REFERENCES}

1. Haugen BR, Alexander EK, Bible KC, Doherty GM, Mandel SJ, Nikiforov YE, et al. American Thyroid Association Management Guidelines for Adult Patients with Thyroid Nodules and Differentiated Thyroid Cancer: The American Thyroid Association Guidelines Task Force on Thyroid Nodules and Differentiated Thyroid Cancer. Thyroid. 2016;26(1): 1-133. DOI:10.1089/thy.2015.0020.

2. Nechyporuk VM,. Zaichko NV, Korda MM. [Effect of thyroid hormones on the sulfur-containing amino acids remethylation and transsulfuration pathways in rats organs]. Medychna ta klinichna khimiia. 2017;19(1): 12-6. Ukrainian.

3. Orzechowska-Pawilojc A, Siekierska-Hellmann M, Syrenicz A, Sworczak K. Homocysteine, folate, and cobalamin levels in hyperthyroid women before and after treatment. Endokrynol Pol. 2009;60(6): 443-8.

4. Somova OV. Interrelation of organism`s thyroid state and processes of lipid peroxidation. Candidate's thesis. Physiology of human and animals. Kharkiv; 1999. Ukrainian.

5. OleynikVA, MarkovVV, Gulevatyy SV, MatyashchukSI, Sovenko TK. [Clinical protocol of post-surgical management of patients with differentiated thyroid cancer]. Liky Ukrainy. 2010;146(10): 73-75. Ukrainian.

6. Marushchak MI. [The role of reactive oxygen species in the development and progression of acute lung injury in experiments]. Medychna khimiia. 2012;14(1): 104-8. Ukrainian.

7. Antonishin IV, Marushchak MI, Denefil OV. [The state of lipid peroxidation in experimental diet-induced alimentary obesity]. Medychna khimiia. 2014;16(3): 61-5. Ukrainian.

8. Kozhemyakin YuM, Khromov OS, Filonenko MA, Sayfetdinova HA. Scientific and practical recommendations
И. Д. Стальная Т. Г. Гаришвили // Современные методы в биохимии / ред. В. Н. Орехович. - М. : Медицина, 1977. - C. 66-68.

15. Чевари С. Роль супероксиддисмутазы в окислительных процессах клетки и метод определения ее в биологических материалах / С. Чевари, И. Чаба, й. Секкей // Лаб. дело. - 1985. - № 11. - С. 678-681.

16. Метод определения активности каталазы / М. А. Королюк, Л. И. Иванова, И. Г. Майорова [и др.] // Лаб. дело. - 1988. - № 1. - С.16-19.

for keeping laboratory animals and working with them. [Hayково-практичні рекомендації з утримання лабораторних тварин та роботи з ним] Kyiv: Avitsenna; 2002. Ukrainian.

9. Stepanyuk HI, Shevchuk OK. [Method of anesthesia in rats during gastric surgery]. UA 3386. 2004, published. 15.11.2004. Bul.11. Ukrainian.

10. Kharkevich D.A. Pharmacology: a textbook for students of medical universities. [Фармакология: учебник для студ. мед. вузов] Moscow: Meditsina;1981. Russian.

11. Pavlov AA, Podrez YeV. [Place of a2-agonists in combined anesthesia. Meditsina neotlozhnikh sostoyaniy]. 2014;8(63): 9-12. Ukrainian.

12. GavrilovVB, Mishkorudnaya MI. [Spectrophotometric determination of the content of lipid hydroperoxides in blood plasma]. Lab delo. 1983;3:33-6. Russian.

13. Rom-Buguslavskaya ES, Somova EV, Grinchenko TS. [Lipid peroxidation in patients with diffuse toxic goiter and hypothyroidism]. Vrach delo. 1998;1: 88-91. Russian.

14. Stalnaya ID, Garishvili TG. Method for the determination of malonic dialdehyde using thiobarbituric acid. [Метод определения малонового диальдегида с помощью тиобарбитуровой кислоты]. Orekhovich VN, ed. Modern methods in biochemistry. [Современные методы в биохимии]. Moscow: Meditsina; 1977. Russian.

15. Chevari C, Chaba I, Sekkey J. [The role of superoxide dismutase in the oxidative processes of the cell and the method for its determination in biological materials]. Lab delo. 1985;11: 678-81. Russian.

16. Korolyuk MA, Ivanova LI, Mayorova IG, Tokarev VE. [Method for determination of catalase activity]. Lab delo. 1988;1: 16-9. Russian. 